University of Nebraska - Lincoln

DigitalCommons@University of Nebraska - Lincoln

Publications from USDA-ARS / UNL Faculty

U.S. Department of Agriculture: Agricultural

Research Service, Lincoln, Nebraska

4-8-2019

\title{
Yield determination of maize hybrids under limited irrigation
}

Jin Zhao

Aarhus University \& Texas A\&M AgriLife Research and Extension Center at Amarillo

Qingwu Xue

Texas A\&M AgriLife Research and Extension Center at Amarillo, qxue@ag.tamu.edu

Baozhen Hao

Xinxiang University

Thomas H. Marek

Texas A\&M AgriLife Research and Extension Center at Amarillo

Kirk E. Jessup

Texas A\&M AgriLife Research and Extension Center at Amarillo

See next page for additional authors

Follow this and additional works at: https://digitalcommons.unl.edu/usdaarsfacpub

Zhao, Jin; Xue, Qingwu; Hao, Baozhen; Marek, Thomas H.; Jessup, Kirk E.; Xu, Wenwei; Bean, Brent W.; and Colaizzi, Paul D., "Yield determination of maize hybrids under limited irrigation" (2019). Publications from USDA-ARS / UNL Faculty. 2189.

https://digitalcommons.unl.edu/usdaarsfacpub/2189

This Article is brought to you for free and open access by the U.S. Department of Agriculture: Agricultural Research Service, Lincoln, Nebraska at DigitalCommons@University of Nebraska - Lincoln. It has been accepted for inclusion in Publications from USDA-ARS / UNL Faculty by an authorized administrator of DigitalCommons@University of Nebraska - Lincoln. 


\section{Authors}

Jin Zhao, Qingwu Xue, Baozhen Hao, Thomas H. Marek, Kirk E. Jessup, Wenwei Xu, Brent W. Bean, and Paul D. Colaizzi 


\title{
Yield determination of maize hybrids under limited irrigation
}

\author{
Jin Zhao a,b, Qingwu Xue ${ }^{b}$, Baozhen Hao ${ }^{c}$, Thomas H. Marek ${ }^{b}$, Kirk E. Jessup ${ }^{b}$, \\ Wenwei $\mathrm{Xu}^{\mathrm{d}}$, Brent W. Bean ${ }^{\mathrm{e}}$, and Paul D. Colaizzi ${ }^{\mathrm{f}}$

\begin{abstract}
aDepartment of Agroecology, Aarhus University, Tjele, Denmark; ${ }^{\mathrm{b} T e x a s}$ A\&M AgriLife Research and Extension Center at Amarillo, Amarillo, TX, USA; 'School of Science and Technology, Xinxiang University, Xinxiang, Henan, China; ${ }^{\mathrm{D} T e x a s ~ A \& M ~ A g r i L i f e ~ R e s e a r c h ~ a n d ~ E x t e n s i o n ~ C e n t e r ~ a t ~ L u b b o c k, ~}$ Lubbock, TX, USA; 'United Sorghum Checkoff, Lubbock, TX, USA; fUSDA-ARS, Conservation and Production Research Laboratory, Bushland, TX, USA
\end{abstract}

\begin{abstract}
Hybrid adoption, irrigation, and planting density are important factors for maize (Zea mays L.) production in semiarid regions. For this study, a 2-yr field experiment was conducted in the Texas High Plains to investigate maize yield determination, seasonal evapotranspiration (ETc), and water-use efficiency (WUE) under limited irrigation. Two hybrids (N74R, a conventional hybrid, and $\mathrm{N} 75 \mathrm{H}$, a drought-tolerant (DT) hybrid) were planted at three water regimes $\left(I_{100}, I_{75}\right.$, and $I_{50}$, referring to $100 \%, 75 \%$, and $50 \%$ of the evapotranspiration requirement) and three planting densities (PD 6 , PD 8 , and PD 10, referring to 6,8 , and 10 seeds $\mathrm{m}^{-2}$ ). At $\mathrm{I}_{50}$, drought stress reduced grain yield by $4.78 \mathrm{t} / \mathrm{ha}$ for the conventional hybrid but only $4.22 \mathrm{t} / \mathrm{ha}$ for the DT hybrid, when compared to $I_{100}$. Although ETc decreased at $I_{75}$ and $I_{50}$, the highest WUE was found at $\mathrm{I}_{75}$. The DT hybrid did not yield more than the conventional hybrid but had greater yield stability at lower water regimes and extracted less soil water. Drought decreased biomass, harvest index, and kernel weight but did not affect kernel number. Higher planting densities increased biomass and kernel number but decreased kernel weight. Kernel number and kernel weight of the conventional hybrid were more sensitive to planting density than the DT hybrid. These data demonstrated that limited irrigation at $\mathrm{I}_{75}$ is an effective way to save water and maintain the maize yield in semiarid areas, and that DT hybrid shows a greater yield stability to plant density under water stress.
\end{abstract}

\section{ARTICLE HISTORY}

Received 2 February 2019

Accepted 8 April 2019

\section{KEYWORDS}

Drought-tolerant hybrid; planting density; water use; water-use efficiency; Zea mays $\mathrm{L}$

\section{Introduction}

Maize (Zea mays L.) plays an important role in global food security. However, with climate change, severe and frequent droughts will greatly reduce soil water available for plant uptake (Rurinda et al. 2015). In such conditions, the increasing shortage of freshwater will be the most limiting factor to maize productivity, particularly under arid or semi-arid climatic conditions (Wang et al. 2017). Limited irrigation, with an amount less than the crop water requirement, has been recognized as a viable water-saving technique in preparation for future

CONTACT Qingwu Xue qxue@ag.tamu.edu $\Theta$ Texas A\&M AgriLife Research and Extension Center at Amarillo, Amarillo, TX 79106, USA 
water-shortage scenarios. The mild stress developed by limited irrigation has minimal effects on the yield, but increases water-use efficiency (WUE), resulting in significant water savings (Gheysari et al. 2017; Wang et al. 2017).

Adoption of new hybrids possessing drought-tolerant traits has been recognized to be an important intervention for water limited conditions (Tollenaar and Lee 2002; Campos et al. 2006). Under water limited conditions, these drought-tolerant (DT) hybrids had yield advantages over conventional or drought-sensitive hybrids in several studies (Boomsma and Vyn 2008; Cooper et al. 2014; Sammons et al. 2014; Hao et al. 2015a, 2015b). Therefore, greater yield stability through improved drought tolerance is a common objective in breeding programs in the US corn-belt (Cooper et al. 2014). Moreover, identification and understanding of traits associated with improved crop drought tolerance have been the focus for hybrid maize development (Zhan, Schneider, and Lynch 2015).

Finally, apart from limited irrigation and drought-tolerant hybrids, adjusting planting density is another important practice to increase the maize yield per unit of scarce water (Passioura 2006), since the optimum density is related to soil water availability (Ren, Sun, and Wang 2016). During the past 30 years, due to genetic improvements, increased planting density contributed to greater maize yield worldwide (Duvick 2005; Testa, Reyneri, and Blandino 2016; Jia et al. 2018). Compared with older hybrids, new hybrids yielded more at higher densities (Echarte et al. 2000; Tokatlidis et al. 2004; Duvick 2005; Qian et al. 2016). As a result, the average maize planting density has increased from 3 plants $/ \mathrm{m}^{2}$ in the 1930s to 8 plants $/ \mathrm{m}^{2}$ currently in the US Corn Belt (Duvick 2005; Li et al. 2015). However, crop growth showed a quadratic response to planting density (Tollenaar and Wu 1999; Echarte et al. 2000), and the density that is greater than optimum may cause accelerated leaf senescence rate, thin stems, decreased biomass, more water requirement, and lower yield (Nyakudya and Stroosnijder 2014). In previous studies, optimal densities for maize were reported between 8 to 11 plants $/ \mathrm{m}^{2}$ (Li et al. 2015; Ren, Sun, and Wang 2016; Testa, Reyneri, and Blandino 2016). Maize yield response to planting density is inconsistent across environments (Milander et al. 2016), and generally, the optimal planting density is higher under full irrigation than limited irrigation or dryland in the same place (Ren, Sun, and Wang 2016).

The Texas High Plains (THP) is a highly productive maize area under irrigation (Howell 2001; Farfan et al. 2013; Xue et al. 2017). However, the irrigation source, Ogallala Aquifer, continues to decline and threatens the sustainable maize production in the area (Scanlon et al. 2010; Ziolkowska 2015). Several recent studies have shown a yield benefit in DT hybrids under limited irrigation. The DT hybrids had greater biomass, harvest index (HI), and higher resource use efficiency (e.g., water and radiation) (Hao et al. 2015a, 2015b, 2016; Mounce et al. 2016). However, yield determination of hybrids under different planting densities was not addressed. The objective of this study was to investigate the maize yield determination at planting densities under limited irrigation. 


\section{Materials and methods}

\section{Experimental site}

Field experiments were conducted at the Texas A\&M AgriLife North Plains Research Field, near Etter, Texas $\left(35^{\circ} 60^{\prime} \mathrm{N}, 101^{\circ} 59^{\prime} \mathrm{W}\right.$; elevation $1114 \mathrm{~m}$ above mean sea level), during the 2013 and 2014 growing seasons. The soil type in the experimental area was a Sherm silty clay loam. Meteorological data for the two growing seasons was obtained from an agricultural meteorological station located at the experimental site, which was part of the Texas High Plains Evapotranspiration (TXHPET) network (Marek et al. 2011).

\section{Experimental design and treatments}

The experimental design was a split plot design with four replications. Irrigation treatment was the main plot with planting density as sub-plot factor and hybrid as sub-sub-plot factor. There were three irrigation treatments: $\mathrm{I}_{100}, \mathrm{I}_{75}$, and $\mathrm{I}_{50}$, corresponding to $100 \%, 75 \%$, and $50 \%$ of the crop evapotranspiration requirement, respectively. And there were three planting densities: PD 10, PD 8, and PD 6 , corresponding to 10,8 , and 6 seeds $/ \mathrm{m}^{2}$. All plots were irrigated with a center pivot irrigation system using low elevation spray application heads. In each season, no irrigation was applied before planting. After planting, initial irrigation with a uniform rate for all treatments was applied to ensure uniform emergence and stands for all plots. For the $I_{100}$ treatment, irrigation scheduling was determined according to maize crop evapotranspiration $\left(\mathrm{ET}_{\mathrm{c}}\right)$ calculated using a multiple stage crop coefficient method with the TXHPET website. Maize crop coefficients were previously determined using the large lysimeters at the USDAARS facility at Bushland, Texas. Plant available soil water (PAW) was estimated as the difference between current root zone soil water and that at the lower limit $(-1.5 \mathrm{MPa})$ (Marek et al. 2011). The initial soil water content in the root zone was measured by the gravimetric method using soil cores. Then, the daily soil water balance was calculated by using the soil water of the first day and subtracting $\mathrm{ET}_{c}$, while adding effective precipitation and irrigation values using a 90\% application efficiency value. Irrigation events were initiated generally when the root zone soil PAW reached 50\%. After crop establishment, for the $\mathrm{I}_{75}$ and $\mathrm{I}_{50}$ treatments, irrigation continued at the same frequency as that of the $I_{100}$ treatment, but the irrigation amount was reduced proportionally to that of the $\mathrm{I}_{100}$ treatment, by using nozzles with a reduced rate. The total irrigation amounts for the $I_{100}, I_{75}$, and $I_{50}$ treatments were respectively 608,474 , and $340 \mathrm{~mm}$ in 2013, and 651, 490, and $326 \mathrm{~mm}$ in 2014 (Figure 1).

Two Syngenta hybrids were selected, a conventional hybrid, N74R, with 113-day relative maturity, and a DT hybrid (i.e., having the Agrisure Artesian drought tolerant trait), $\mathrm{N} 75 \mathrm{H}$, with 114-day relative maturity. Syngenta rated drought tolerance using a drought score ranging from 1 to 9 (where 

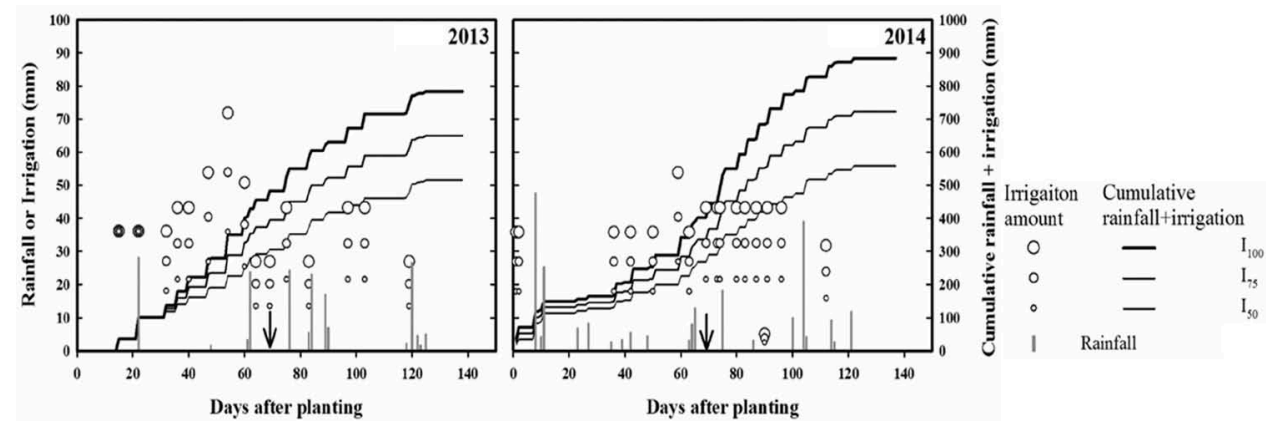

Figure 1. Rainfall and irrigation, and cumulative rainfall and irrigation during the 2013 and 2014 maize growing seasons at Etter, Texas.

$1=$ Excellent, 9 = Poor). The drought score was 1 for N75 (Agrisure Artesian hybrid) and 2 for N74R (conventional hybrid). The maize was planted on 16 May 2013, and 14 May 2014, using a four-row Max-Emerge (John Deere, East Moline, IL) planter. The plots were harvested in the middle of October in each season, using a Kincaid 8-XP Plot Combine (Kincaid Equipment Manufacturing, Haven, KS).

Each plot was $3.0 \mathrm{~m}$ wide and $9.1 \mathrm{~m}$ long and consisted of four rows spaced at $0.76 \mathrm{~m}$. The cropping system was a corn-wheat rotation with strip tillage. The field was fertilized before planting at 290-109-0-11 (N-P-K-S) kg/ ha in 2014, based on soil testing. In 2013, 100-67-0-0 (N-P-K-S) kg/ha was applied before planting, and $100 \mathrm{~kg} / \mathrm{ha} \mathrm{N}$ was applied by fertigation during the growing season. Weed control involved herbicide applications at preplant and post-emergence. One aerial application of Oberon (spiromesifen) was made for spider mite (Tetranychus urticae) control in 2013.

\section{Measurements}

In 2013, gravimetric soil water contents were determined by taking soil cores at $0-0.15,0.15-0.3,0.3-0.6,0.6-0.9$, and $0.9-1.2 \mathrm{~m}$ depth at planting and after harvest. Six soil cores were collected in the field of each irrigation level at planting, and one soil core was taken in each plot after harvest. Gravimetric soil water in each depth was converted to volumetric water by multiplying by the soil bulk density, which was also measured by soil cores. Crop seasonal ET was determined by summing the precipitation, applied irrigation water, and the difference of soil water in the $0-1.2 \mathrm{~m}$ profile between planting and post-harvest. Surface runoff was negligible when calculating ET due to leveled plots. Water-use efficiency $\left(\mathrm{kg} / \mathrm{m}^{3}\right)$ was calculated as the ratio of grain yield and seasonal ET. The water stress index (WSI) was calculated as (1-ET/ET $)$ for all the plots. In 2014, the soil water content at planting and harvest were only measured in the plots with one planting density $\left(8\right.$ seeds $\left./ \mathrm{m}^{2}\right)$. As such, ET data were not reported because our focus was on 
planting density effect. In addition, the effect of irrigation on ET for these hybrids was reported from another study (Zhao et al. 2018).

To better understand the soil water extraction over the growing season, the volumetric soil water content $\left(\mathrm{SWC}, \mathrm{cm}^{3} / \mathrm{cm}^{3}\right.$ ) in PD 8 was measured from V8 stage to maturity by neutron moisture meter [Model 503 DR 1.5, Instrotek (Campbell Pacific Nuclear), Concord, Calif.] for the two hybrids in 2013. Soil water $(\mathrm{mm})$ for each depth was calculated from the volumetric soil water content multiplied by the corresponding depth increment. The total profile soil $(0-2.0 \mathrm{~m})$ water was the sum of the soil water from 0 to $2.0 \mathrm{~m}$ deep. Net soil water extraction (SWE, $\mathrm{mm}$ ) in the $0-2.0 \mathrm{~m}$ profile was calculated as the difference in soil water between the two dates.

In both seasons, biomass, grain yield, kernel number, and kernel weight were measured at physiological maturity. Six plants were hand harvested from the outer two rows in each plot. These six plants were separated into stover, cobs, and grain, which were oven-dried at $70^{\circ} \mathrm{C}$ until constant weight. HI was calculated as the ratio of the grain weight ( $0 \%$ moisture) to the total aboveground plant biomass. Kernel weight ( $0 \%$ moisture) was measured by weighing 250 randomly selected seeds, and the values were adjusted to a water content of $155 \mathrm{~g} / \mathrm{kg}$ (wet basis) for statistical analysis. Kernel number per square meter was calculated based on single kernel weight and the total kernel weight per square meter. Grain yield was determined by harvesting the two center rows with a plot combine, and adjusting the water content to $155 \mathrm{~g} / \mathrm{kg}$ (wet basis) for statistical analysis.

\section{Statistical analysis}

Statistical analysis was conducted using the SAS v9.4 statistical program (SAS Institute Inc 2014). Analysis of variance (ANOVA) was conducted by the PROC MIXED using split-split-plot design. Year was treated as main plot, water regime as sub-plot, and the combination of hybrid and planting density as sub-sub-plot, and appropriate error terms were used for different effects. Replication was considered a random effect. Mean values were compared by least significant difference (LSD) at the $5 \%$ level. The regression analysis was conducted by PROC REG procedure.

\section{Results}

\section{Weather conditions}

The monthly mean maximum and minimum temperatures during the growing season (May to October) were $29.7^{\circ} \mathrm{C}$ and $13.0^{\circ} \mathrm{C}$ in 2013 , and $28.9^{\circ} \mathrm{C}$ and $13.1^{\circ} \mathrm{C}$ in 2014 , which were close to the $17-y r(1995-2011)$ average values $\left(29.2^{\circ} \mathrm{C}\right.$ and $12.9^{\circ} \mathrm{C}$ ) (Table 1). The total precipitation during the growing season was $196 \mathrm{~mm}$ in 2013 and $252 \mathrm{~mm}$ in 2014, which was less than the 17-yr average of $291 \mathrm{~mm}$ at the experimental site. In 2013, only $4 \mathrm{~mm}$ precipitation was 
Table 1. Summary of monthly mean maximum temperature $\left(T_{\max }\right)$, minimum temperature $\left(T_{\min }\right)$, reference evapotranspiration $\left(\mathrm{ET}_{0}\right)$ and total rainfall during the growing seasons of 2013 and 2014, and the 17-year (1995-2011) average at Etter, Texas.

\begin{tabular}{lcccccccc}
\hline Parameter & Year & May & June & July & August & September & October & Mean/Total \\
\hline $\mathrm{T}_{\max }\left({ }^{\circ} \mathrm{C}\right)$ & 2013 & 27.5 & 33.6 & 31.9 & 32.6 & 30.0 & 22.6 & 29.7 \\
& 2014 & 27.0 & 30.9 & 31.8 & 33.8 & 26.7 & 22.9 & 28.9 \\
& $17-y r$. avg. & 26.7 & 31.6 & 33.6 & 32.5 & 28.6 & 22.3 & 29.2 \\
$\mathrm{~T}_{\min }\left({ }^{\circ} \mathrm{C}\right)$ & 2013 & 8.8 & 16.6 & 17.4 & 17.3 & 14.2 & 3.8 & 13.0 \\
& 2014 & 8.8 & 15.8 & 17.3 & 16.6 & 13.4 & 6.9 & 13.1 \\
& $17-y r$. avg. & 9.9 & 15.2 & 17.4 & 16.9 & 12.4 & 5.4 & 12.9 \\
$\mathrm{ET}_{0}(\mathrm{~mm})$ & 2013 & 224 & 250 & 197 & 180 & 152 & 126 & 1129 \\
& 2014 & 204 & 210 & 201 & 199 & 125 & 102 & 1040 \\
& $17-y r$. avg. & 194 & 214 & 210 & 181 & 143 & 108 & 1050 \\
Precipitation & 2013 & 4 & 30 & 58 & 53 & 43 & 7 & 196 \\
$(\mathrm{~mm})$ & 2014 & 80 & 33 & 50 & 59 & 24 & 4 & 252 \\
& $17-y r$. avg. & 37 & 56 & 57 & 58 & 36 & 47 & 291 \\
\hline
\end{tabular}

observed in May, while the $17-y r$ average was $37 \mathrm{~mm}$. Much less precipitation was observed in June ( $30 \mathrm{~mm}$ and $33 \mathrm{~mm}$ ) and October $(7 \mathrm{~mm}$ and $4 \mathrm{~mm})$ than the long term averages ( $56 \mathrm{~mm}$ and $47 \mathrm{~mm}$ ) during both 2013 and 2014 seasons. Total seasonal reference ET $\left(\mathrm{ET}_{0}\right)$ was $1129 \mathrm{~mm}$ in 2013 and $1040 \mathrm{~mm}$ in 2014, which means seasonal rainfall only accounted for $17 \%$ and $24 \%$ of seasonal $\mathrm{ET}_{0}$, respectively.

\section{Grain yield, seasonal ET, and WUE}

Grain yield was affected by water regime, plant density, and hybrid, but no interactions (Table 2). For both seasons, no differences in grain yield were found between $\mathrm{I}_{100}$ and $\mathrm{I}_{75}$ for both hybrids. In the $\mathrm{I}_{50}$ treatment, compared to the

Table 2. Analysis of variance $(\mathrm{P}>\mathrm{F})$ of maize biomass $(\mathrm{BM})$ at maturity, harvest index $(\mathrm{HI})$, kernel weight $(\mathrm{KW})$, kernel number $(\mathrm{KN})$, grain yield $(\mathrm{GY})$, seasonal crop evapotranspiration $\left(\mathrm{ET}_{\mathrm{c}}\right)$, and water use efficiency (WUE) as affected by year (Y), water regime (WR), hybrid (HB), and plant density (PD).

\begin{tabular}{lcccccccc}
\hline Effect & d.f. & $\mathrm{BM}$ & $\mathrm{HI}$ & $\mathrm{KW}$ & $\mathrm{KN}$ & $\mathrm{GY}$ & $\mathrm{ET}_{\mathrm{c}}{ }^{\dagger}$ & WUE† \\
\hline Year (Y) & 1 & 0.1295 & 0.1309 & 0.7341 & 0.4506 & 0.0114 & & \\
Water regime (WR) & 2 & $<\mathbf{0 . 0 0 0 1}$ & $\mathbf{0 . 0 0 0 5}$ & $<.0001$ & $\mathbf{0 . 0 2 6 5}$ & $<.0001$ & $\mathbf{0 . 0 0 0 1}$ & 0.1604 \\
Hybrid (HB) & 1 & 0.6099 & $\mathbf{0 . 0 1 3 7}$ & 0.0753 & $\mathbf{0 . 0 3 8 7}$ & $\mathbf{0 . 0 0 0 1}$ & 0.8142 & 0.0705 \\
Plant density (PD) & 2 & $\mathbf{0 . 0 2 1 8}$ & 0.6317 & 0.0001 & 0.0009 & 0.0266 & 0.2893 & 0.4631 \\
Y $\times$ WR & 2 & 0.1060 & 0.1748 & 0.1028 & 0.6206 & 0.0784 & & \\
Y $\times$ HB & 1 & 0.9571 & 0.3693 & 0.7916 & 0.6776 & 0.3205 & & \\
Y $\times$ PD & 2 & $\mathbf{0 . 0 3 7 0}$ & 0.5343 & 0.2013 & 0.0325 & 0.4122 & & \\
WR $\times$ HB & 2 & 0.4980 & 0.2496 & 0.9816 & 0.8094 & 0.4130 & $\mathbf{0 . 0 2 0 7}$ & 0.8496 \\
WR $\times$ PD & 4 & 0.7364 & 0.1571 & 0.4482 & 0.8086 & 0.2849 & 0.0714 & 0.4574 \\
HB $\times$ PD & 2 & 0.2701 & 0.0014 & 0.2207 & 0.3216 & 0.1305 & 0.0868 & $\mathbf{0 . 0 3 5 9}$ \\
Y $\times$ WR $\times$ HB & 2 & 0.1780 & 0.1403 & 0.0998 & 0.1235 & 0.5034 & & \\
Y $\times$ WR $\times$ PD & 4 & 0.8416 & 0.1704 & 0.5662 & 0.9680 & 0.2193 & & \\
Y $\times$ HB $\times$ PD & 2 & 0.8298 & 0.2619 & 0.0650 & 0.7416 & 0.0623 & & \\
WR $\times$ HB $\times$ PD & 4 & 0.9055 & 0.1152 & 0.6530 & 0.8462 & 0.7567 & 0.0701 & $\mathbf{0 . 0 4 1 3}$ \\
Y $\times$ WR $\times$ HB $\times$ PD & 4 & 0.1312 & 0.8852 & 0.1702 & 0.6705 & $\mathbf{0 . 0 5 0 6}$ & & \\
\hline
\end{tabular}

tETc and WUE data were only for 2013. Therefore, there was no year effect. 
$\mathrm{I}_{100}$ and $\mathrm{I}_{75}$ treatments, grain yield was reduced by $4.78 \mathrm{t} / \mathrm{ha}$ and $4.53 \mathrm{t} / \mathrm{ha}$ for $\mathrm{N} 74 \mathrm{R}$, and $4.22 \mathrm{t} / \mathrm{ha}$ and $3.75 \mathrm{t} / \mathrm{ha}$ for $\mathrm{N} 75 \mathrm{H}$, respectively $(\mathrm{P}<0.05$, Figure 2$)$. However, the grain yield of the two hybrids showed different responses to planting density in both years (Figure 2). There were no yield differences among the three planting densities for N74R, while grain yield for $\mathrm{N} 75 \mathrm{H}$ increased as planting density increased. Compared to PD 6, N75H in PD 10 had 1.48 t/ha and 1.46 t/ha greater $(\mathrm{P}<0.05)$ grain yield in 2013 and 2014.

In 2013, the effects of water regime on the seasonal ET and WUE were significant for both hybrids, and seasonal ET decreased with decreasing water supply (Table 3 ). Compared to $\mathrm{I}_{100}$, the seasonal $\mathrm{ET}$ in $\mathrm{I}_{75}$ and $\mathrm{I}_{50}$ was reduced by $88 \mathrm{~mm}$ and $175 \mathrm{~mm}$ for N74R, and $104 \mathrm{~mm}$ and $206 \mathrm{~mm}$ for N75H (Table 3). The highest WUE was found at $\mathrm{I}_{75}$ for both hybrids $\left(2.39 \mathrm{~kg} / \mathrm{m}^{3}\right.$ and $\left.2.26 \mathrm{~kg} / \mathrm{m}^{3}\right)$, and no differences were found between $\mathrm{I}_{100}$ and $\mathrm{I}_{50}$. The effects of planting density on ETc and WUE were different between the two hybrids. For N74R, plants at low density had lower ETc but planting density did not affect ETc for N75H. For both hybrids at $\mathrm{I}_{100}$, WUE increased as PD increased. At lower water regimes $\mathrm{I} 75$ and I50), there were no differences in WUE among planting densities for N74R. For $\mathrm{N} 75 \mathrm{H}$, WUE increased as the density increased to 10 plants $/ \mathrm{m}^{2}$ (Table 3).
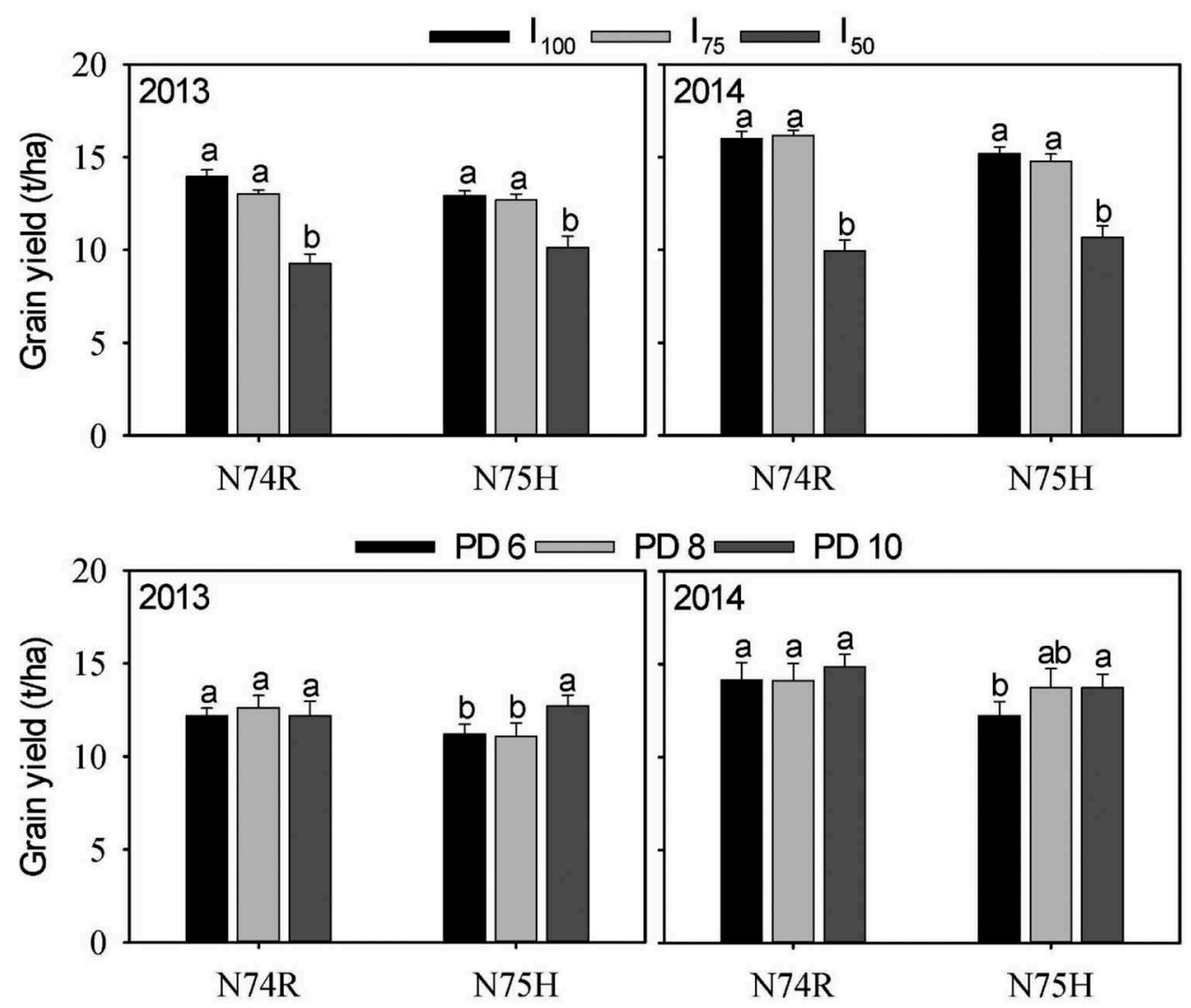

Figure 2. Grain yield of the two maize hybrids under three water regimes $\left(I_{100}, I_{75}\right.$ and $\left.I_{50}\right)$ and three plant densities (PD 6, PD 8 and PD 10) in 2013 and 2014. 
Table 3. Maize seasonal evapotranspiration (ETc) and water use efficiency (WUE) for the two hybrids at three plant densities and three water regimes at Etter, Texas in 2013.

\begin{tabular}{|c|c|c|c|c|c|}
\hline \multirow{2}{*}{$\frac{\text { Water }}{\text { regime }}$} & \multirow{2}{*}{$\begin{array}{c}\text { Plant } \\
\text { density } \\
\text { (PD) }\end{array}$} & \multicolumn{2}{|c|}{ N74R } & \multicolumn{2}{|c|}{$\mathrm{N} 75 \mathrm{H}$} \\
\hline & & $\begin{array}{l}\text { ETc } \\
\mathrm{mm}\end{array}$ & $\begin{array}{l}\text { WUE } \\
\mathrm{kg} / \mathrm{m}^{3}\end{array}$ & $\begin{array}{l}\mathrm{ETc} \\
\mathrm{mm}\end{array}$ & $\begin{array}{l}\text { WUE } \\
\mathrm{kg} / \mathrm{m}^{3}\end{array}$ \\
\hline \multirow[t]{4}{*}{$\mathrm{I}_{100}$} & 6 & $637 \mathrm{bt}$ & $1.99 b$ & $662 a$ & $1.85 b$ \\
\hline & 8 & $667 a$ & $2.18 a b$ & 659a & 2.01ab \\
\hline & 10 & $632 \mathrm{~b}$ & $2.36 a$ & 663a & 2.03a \\
\hline & Mean & 646At & $2.18 \mathrm{AB}$ & $662 A$ & $1.96 \mathrm{~B}$ \\
\hline \multirow[t]{4}{*}{$\mathrm{I}_{75}$} & 6 & $546 \mathrm{~b}$ & $2.46 a$ & 558a & $2.26 a b$ \\
\hline & 8 & 568a & $2.32 \mathrm{a}$ & $571 a$ & $2.04 \mathrm{~b}$ \\
\hline & 10 & 559ab & $2.39 a$ & $544 a$ & 2.48a \\
\hline & Mean & 558B & $2.39 \mathrm{~A}$ & 558B & $2.26 \mathrm{~A}$ \\
\hline \multirow[t]{4}{*}{$I_{50}$} & 6 & $462 b$ & $2.24 a$ & $467 a$ & $1.81 \mathrm{a}$ \\
\hline & 8 & $461 b$ & $2.26 a$ & 450a & $1.76 a$ \\
\hline & 10 & $486 a$ & $1.65 a$ & 450a & 2.35a \\
\hline & Mean & $471 C$ & 2.02B & $456 \mathrm{C}$ & $1.98 \mathrm{AB}$ \\
\hline
\end{tabular}

† Means followed by different uppercase letters are significantly different among water regimes at the 0.05 probability level; means followed by different lowercase letters are significantly different among planting densities at the 0.05 probability level.

For both hybrids, grain yield decreased linearly as WSI increased (Figure 3). The slope of yield response increased with increasing planting density for N74R. However, the slope of yield response decreased as PD increased for N75H. For N74R, increasing WSI by 0.1 may reduce yield by $1.1,2.1$, and $3.8 \mathrm{t} / \mathrm{ha}$ under PD 6 , PD 8 and PD 10, respectively. For N75H, increasing WSI by 0.1 may reduce yield by 1.6, 1.4, and 1.1 t/ha under PD 6, PD 8, and PD 10.

\section{Biomass, harvest index, kernel number, and kernel weight}

Biomass at maturity was affected by main effects of water regime $(\mathrm{P}<0.01)$ and planting density $(\mathrm{P}=0.03)$ (Table 2$)$. On average, no difference in biomass was found between $\mathrm{I}_{100}$ and $\mathrm{I}_{75}$, but biomass at $\mathrm{I}_{50}$ was less than that at the two other water regimes (Table 4). Moreover, biomass under PD 6 was less than the two other planting densities, while no difference was found between PD 8 and PD 10.

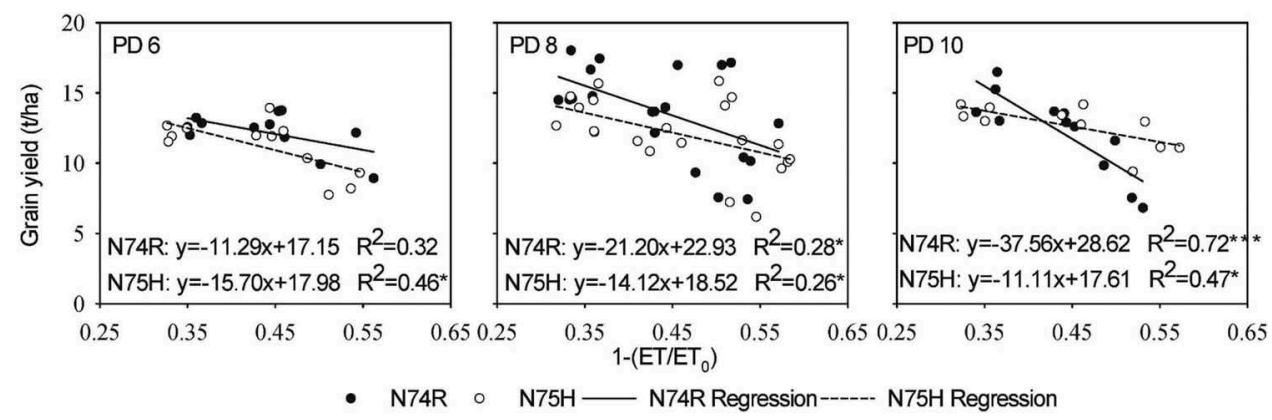

Figure 3. Linear regressions of grain yield versus the stress index based on the ratio of evapotranspiration (ET) and reference evapotranspiration $\left(\mathrm{ET}_{\mathrm{o}}\right)$ for the two hybrids in the two seasons. 
Table 4. Biomass (BM), harvest index ( $\mathrm{HI})$, kernel weight $(\mathrm{KW})$ and kernel number $(\mathrm{KN})$ as affected by the main effects of year, water regime, hybrid and planting density in 2013 and 2014.

\begin{tabular}{lccccc}
\hline & & $\mathrm{BM} \mathrm{t} / \mathrm{ha}$ & $\mathrm{HI}$ & $\mathrm{KW}$ mg/kernel & $\mathrm{KN}$ kernels $/ \mathrm{m}^{2}$ \\
\hline Year & 2013 & $23.02 \mathrm{a} \dagger$ & $0.57 \mathrm{~b}$ & $345.4 \mathrm{a}$ & $4507 \mathrm{a}$ \\
Water regime & 2014 & $21.93 \mathrm{a}$ & $0.58 \mathrm{a}$ & $342.7 \mathrm{a}$ & $4459 \mathrm{a}$ \\
& $\mathrm{I}_{100}$ & $24.42 \mathrm{a}$ & $0.60 \mathrm{a}$ & $382.8 \mathrm{a}$ & $4540 \mathrm{a}$ \\
& $\mathrm{I}_{75}$ & $24.87 \mathrm{a}$ & $0.57 \mathrm{~b}$ & $366.7 \mathrm{~b}$ & $4608 \mathrm{a}$ \\
Hybrid & $\mathrm{I}_{50}$ & $18.14 \mathrm{~b}$ & $0.55 \mathrm{c}$ & $282.6 \mathrm{c}$ & $4301 \mathrm{a}$ \\
& $\mathrm{N} 74 \mathrm{R}$ & $22.66 \mathrm{a}$ & $0.58 \mathrm{a}$ & $338.3 \mathrm{a}$ & $4669 \mathrm{a}$ \\
Planting density & $\mathrm{N} 75 \mathrm{H}$ & $22.30 \mathrm{a}$ & $0.57 \mathrm{~b}$ & $349.8 \mathrm{a}$ & $4297 \mathrm{~b}$ \\
& 6 & $21.08 \mathrm{~b}$ & $0.58 \mathrm{a}$ & $364.1 \mathrm{a}$ & $3990 \mathrm{~b}$ \\
& 8 & $23.21 \mathrm{a}$ & $0.57 \mathrm{a}$ & $336.8 \mathrm{~b}$ & $4704 \mathrm{a}$ \\
& 10 & $23.15 \mathrm{a}$ & $0.57 \mathrm{a}$ & $331.2 \mathrm{~b}$ & $4755 \mathrm{a}$ \\
\hline
\end{tabular}

tMeans in each column for each main effect followed by different letters are significantly different at the 0.05 probability level.

In 2013, average biomass across water regimes and hybrids under PD 6 was less $(\mathrm{P}<0.05)$ than the two other planting densities, while there were no differences among the three planting densities in 2014 (Figure 4).

Harvest index was affected by water regime and hybrid (Table 2). Higher $(\mathrm{P}<0.05) \mathrm{HI}$ was found in 2014 than 2013, and N74R had a slightly higher $\mathrm{HI}$ than $\mathrm{N} 75 \mathrm{H}$ (Table 4). Compared with $\mathrm{HI}$ at $\mathrm{I}_{100}$, water stress at $\mathrm{I}_{75}$ and $\mathrm{I}_{50}$ reduced HI by 0.01 and 0.02 in 2013. However, in 2014, HI dropped more at $\mathrm{I}_{75}$ and $\mathrm{I}_{50}(0.03$ and 0.03$)$, which resulted in a year $\times$ water regime interaction (Figure 5).

Kernel weight was strongly $(\mathrm{P} \leq 0.01)$ affected by water regime and planting density (Table 2). Water stress at $\mathrm{I}_{75}$ and $\mathrm{I}_{50}$ reduced the kernel weight by $16.1 \mathrm{mg} / \mathrm{kernel}$ and $100.2 \mathrm{mg} /$ kernel compared to $\mathrm{I}_{100}$ (Table 4), and the same trend was found in both hybrids in both years (Table 5).

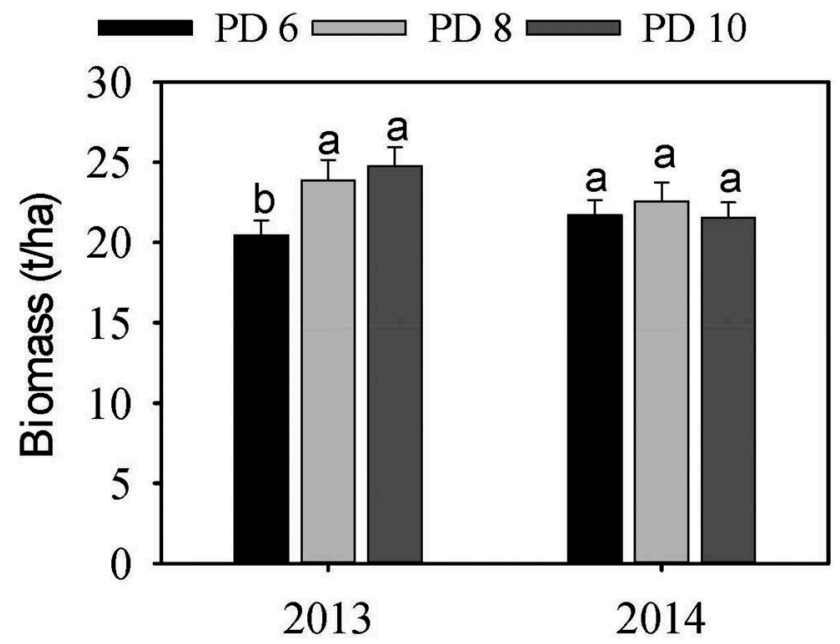

Figure 4. Biomass of the two maize hybrids under three plant densities (PD 6, PD 8 and PD 10) in 2013 and 2014. 


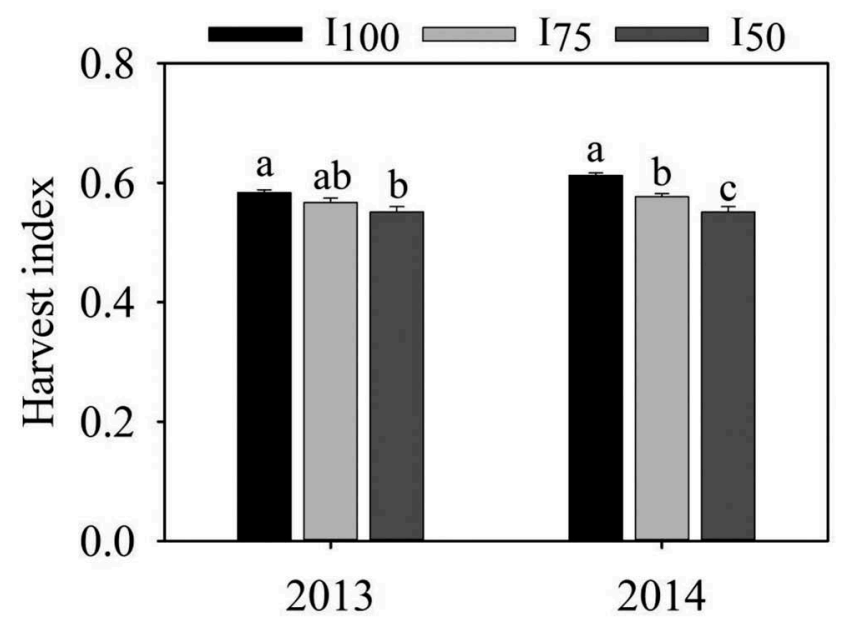

Figure 5. Harvest index $(\mathrm{HI})$ of the two maize hybrids under three water regimes $\left(\mathrm{I}_{100}, \mathrm{I}_{75}\right.$ and $\left.\mathrm{I}_{50}\right)$ in 2013 and 2014.

Table 5. Kernel weight (KW) and kernel number (KN) as affected by year, water regime, and hybrid in 2013 and 2014.

\begin{tabular}{|c|c|c|c|c|c|c|c|}
\hline \multirow[b]{2}{*}{ Year } & \multirow[b]{2}{*}{ Hybrid } & \multicolumn{3}{|c|}{ Kernel weight $\mathrm{mg} / \mathrm{kernel}$} & \multicolumn{3}{|c|}{ Kernel number kernels $/ \mathrm{m}^{2}$} \\
\hline & & $\mathrm{I}_{100}$ & $\mathrm{I}_{75}$ & $I_{50}$ & $\mathrm{I}_{100}$ & $\mathrm{I}_{75}$ & $\mathrm{I}_{50}$ \\
\hline \multirow[t]{3}{*}{2013} & N74R & $381.7 \mathrm{aA} \dagger$ & $356.3 a A$ & $278.4 a B$ & $4800 \mathrm{aA}$ & $4998 a A$ & $4170 \mathrm{aB}$ \\
\hline & $\mathrm{N} 75 \mathrm{H}$ & 398.2aA & 383.1aA & $274.5 \mathrm{aB}$ & $4418 a A$ & $4273 a A$ & $4382 \mathrm{aA}$ \\
\hline & Mean & $390.0 \mathrm{~A}$ & 369.7A & 276.4B & $4609 A$ & $4635 A$ & 4276A \\
\hline \multirow[t]{3}{*}{2014} & N74R & $371.9 \mathrm{aA}$ & 367.3aA & $274.1 \mathrm{aB}$ & $4812 \mathrm{aA}$ & $4626 a A$ & 4699aA \\
\hline & $\mathrm{N} 75 \mathrm{H}$ & $379.4 \mathrm{aA}$ & $360.0 \mathrm{aA}$ & 303.3aB & $4130 \mathrm{bA}$ & $4534 a A$ & 3953aA \\
\hline & Mean & $375.6 \mathrm{~A}$ & 363.7A & 288.7B & $4471 A$ & $4580 \mathrm{~A}$ & 4326A \\
\hline
\end{tabular}

tMeans followed by different uppercase letters are significantly different among water regimes at the 0.05 probability level; means followed by different lowercase letters are significantly different between hybrids at the 0.05 probability level.

Averaged across hybrids, years, and water regimes, higher planting densities under PD 8 and PD 10 decreased the kernel weight by $27.3 \mathrm{mg} / \mathrm{kernel}$ and $32.9 \mathrm{mg} /$ kernel $(\mathrm{P}<0.05)$ compared to PD 6 (Table 4). Both hybrids had lower kernel weights at $\mathrm{I}_{50}$ than at $\mathrm{I}_{100}$ or $\mathrm{I}_{75}$. However, higher planting densities only reduced $(\mathrm{P}<0.05)$ the kernel weight for N74R in 2013, and no differences in kernel weight were found among the three planting densities for N75H (Table 6).

Kernel number $/ \mathrm{m}^{2}$ was only affected by planting density (Table 2 ). Averaged across years, water regimes, and planting densities, N74R had 372 more kernels $\mathrm{m}^{-2}(\mathrm{P}<0.05)$ than $\mathrm{N75H}$ (Table 4$)$ due to more $(\mathrm{P}<0.05)$ kernels for N74R at $\mathrm{I}_{100}$ in 2014 (Table 5). There were no differences in kernel numbers among the three water regimes, except that water stress at $\mathrm{I}_{50}$ reduced kernel numbers $(P<0.05)$ of N74R in 2013. More $(P<0.05)$ kernel numbers were found under PD 8 and PD 10 than under PD 6 in 2013. 
Table 6. Kernel weight (KW) and kernel number (KN) as affected by year, hybrid and planting density in 2013 and 2014.

\begin{tabular}{|c|c|c|c|c|c|c|c|}
\hline \multirow[b]{2}{*}{ Year } & \multirow[b]{2}{*}{ Hybrid } & \multicolumn{3}{|c|}{ Kernel weight mg/kernel } & \multicolumn{3}{|c|}{ Kernel number kernels $/ \mathrm{m}^{2}$} \\
\hline & & PD 6 & PD 8 & PD 10 & PD 6 & PD 8 & PD 10 \\
\hline \multirow[t]{3}{*}{2013} & N74R & 378.6aAt & $329.0 \mathrm{aAB}$ & $308.8 \mathrm{aB}$ & $3652 \mathrm{aC}$ & $4841 \mathrm{aB}$ & $5475 \mathrm{aA}$ \\
\hline & $\mathrm{N} 75 \mathrm{H}$ & $363.6 \mathrm{aA}$ & $351.6 a A$ & $340.5 \mathrm{aA}$ & $3797 a B$ & 4609aA & $4667 \mathrm{bA}$ \\
\hline & Mean & $371.1 A$ & $340.3 A B$ & $324.6 \mathrm{~B}$ & 3725B & 4725A & $5071 A$ \\
\hline \multirow[t]{3}{*}{2014} & N74R & $350.8 \mathrm{aA}$ & $318.5 \mathrm{aA}$ & $344.1 \mathrm{aA}$ & $4441 \mathrm{aA}$ & $4828 a A$ & $4776 \mathrm{aA}$ \\
\hline & $\mathrm{N} 75 \mathrm{H}$ & $363.5 \mathrm{aA}$ & $347.8 \mathrm{aA}$ & $331.4 a A$ & 4069aA & $4537 a A$ & $4103 a A$ \\
\hline & Mean & $357.1 A$ & $333.2 A$ & 337.7A & 4255A & $4682 A$ & $4440 A$ \\
\hline
\end{tabular}

†Means followed by different uppercase letters are significantly different among planting densities at the 0.05 probability level; means followed by different lowercase letters are significantly different between hybrids at the 0.05 probability level.

\section{Correlations and regressions}

For both N74R and N75H, yield increased linearly as biomass, HI, and kernel weight increased $(\mathrm{P}<0.0001)$ (Figure 6). However, the linear relationship between kernels per square meter and grain yield was not significant for both hybrids. That indicated that maize grain yield was largely determined by biomass, HI, and kernel weight.

\section{Soil water extraction}

SWE in the $0-2.0 \mathrm{~m}$ profile from V8 stage to maturity under PD 8 at the three water regimes are shown in Figure 7. At $\mathrm{I}_{100}$, the total net SWE $(0-2.0 \mathrm{~m})$ for both hybrids was negative $(-20 \mathrm{~mm}$ for $\mathrm{N} 74 \mathrm{R}$ and $-39 \mathrm{~mm}$ for $\mathrm{N} 75 \mathrm{H})$. However, N74R extracted a net of $11 \mathrm{~mm}$ from the $0.2-1.0 \mathrm{~m}$ depth and $\mathrm{N} 75 \mathrm{H}$ extracted a net of $6 \mathrm{~mm}$ from the $0.2-0.8 \mathrm{~m}$ depth. At $\mathrm{I}_{75}, \mathrm{~N} 74 \mathrm{R}$ extracted water from the $0-1.0 \mathrm{~m}$ soil depth while $\mathrm{N} 75 \mathrm{H}$ extracted from the $0.2-0.8 \mathrm{~m}$ depth. And N75H extracted less soil water than N74R in all the layers. However, the total net SWE for N74R was $30 \mathrm{~mm}$, while that for N75H was $-17 \mathrm{~mm}$ at $\mathrm{I}_{75}$. The maximum depth of soil water extraction was $1.2 \mathrm{~m}$ for both hybrids at $\mathrm{I}_{50}$, and the total net SWE was $84 \mathrm{~mm}$ for N74R and $69 \mathrm{~mm}$ for $\mathrm{N} 75 \mathrm{H}$.

\section{Discussion}

\section{Grain yield, seasonal ET, and WUE}

Using deficit irrigation together with drought-adapted genotypes is considered a good practice to save water and optimize crop yield in drought regions (Gheysari et al. 2015). In our study, the average grain yields ranged from $10.01 \mathrm{t} / \mathrm{ha}$ to $14.91 \mathrm{t} / \mathrm{ha}$ among the three water regimes, which were within the range (6.4-14.8 $\mathrm{t} / \mathrm{ha}$ ) of previous studies in the THP (Howell et al. 1995; Colaizzi, Evett, and Howell 2011). Irrigation at $\mathrm{I}_{75}$ did not reduce the grain yield for either hybrid in either season (Figure 2). On the other hand, the seasonal ETc reduced 

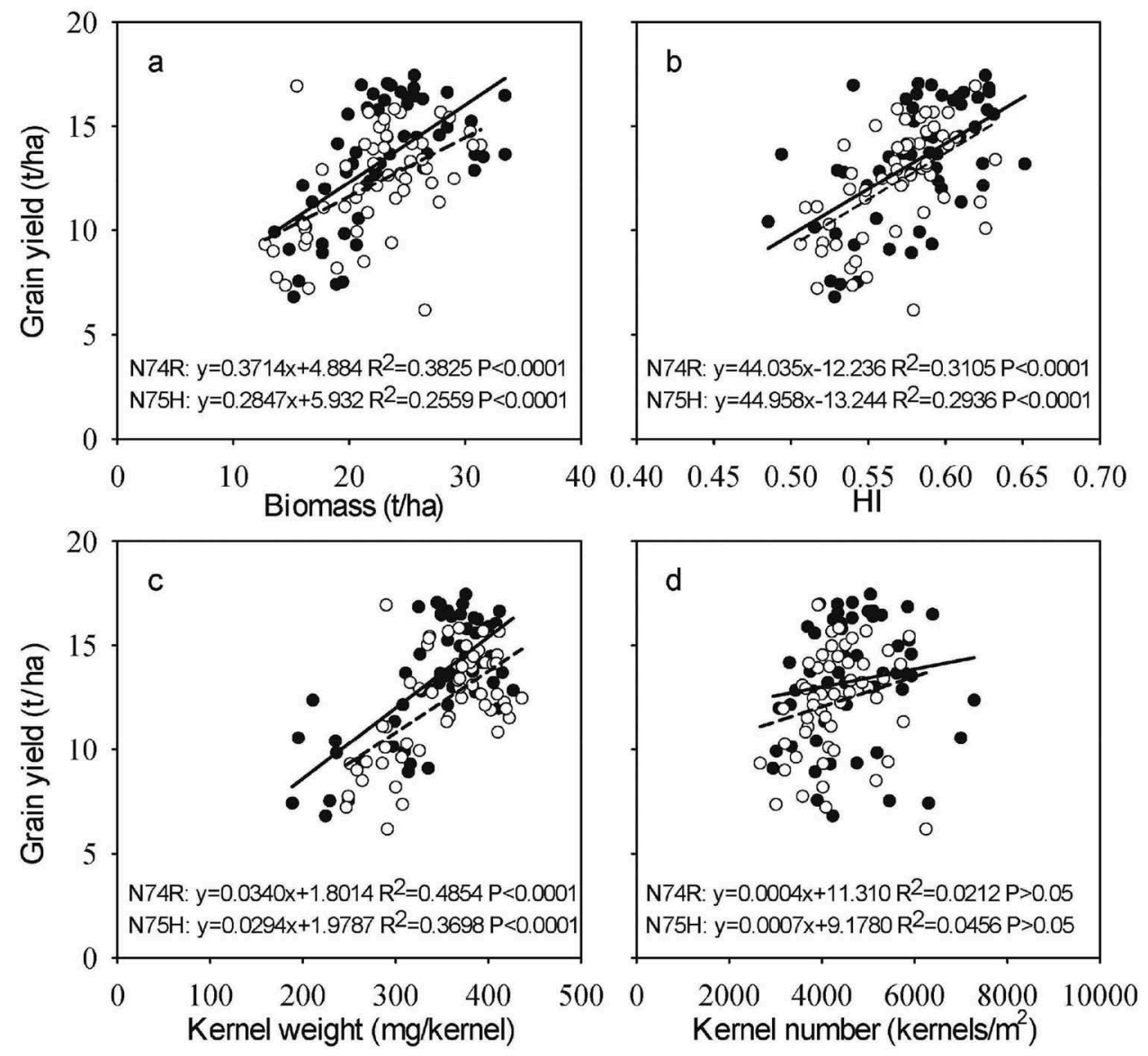

- N74R o N75H

N74R regression

$\mathrm{N} 75 \mathrm{H}$ regression

Figure 6. Linear regressions between grain yield (t/ha) and biomass (t/ha), harvest index, kernel weight $(\mathrm{mg} / \mathrm{kernel})$ and kernel number $\left(\right.$ kernels $\left./ \mathrm{m}^{2}\right)$ for the two hybrids.

\section{Soil water extraction $(\mathrm{mm})$}
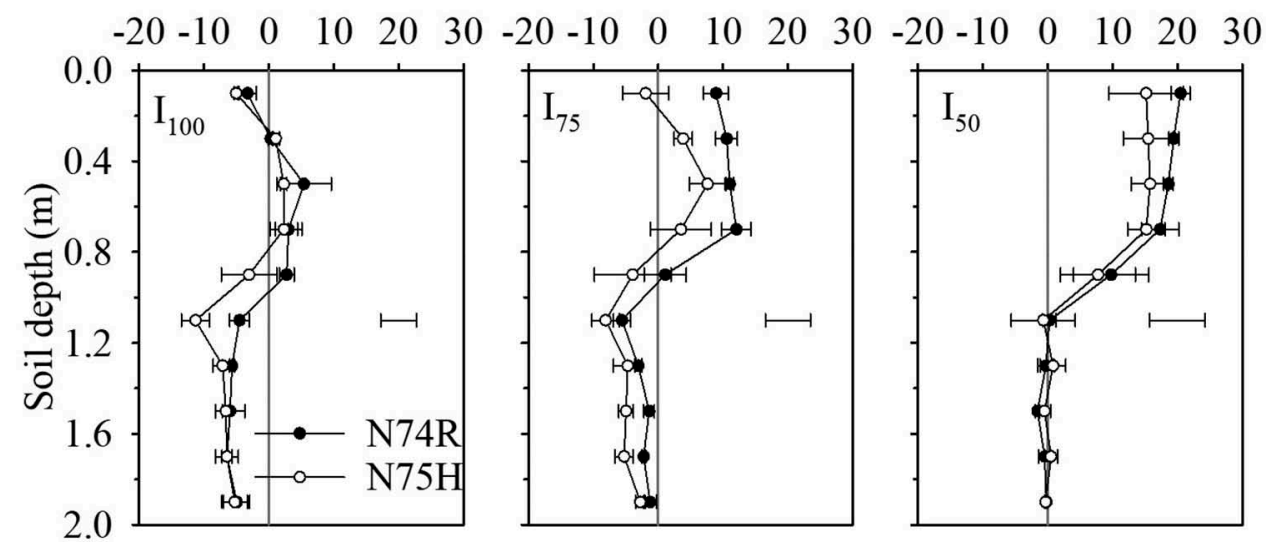

Figure 7. Soil water extraction along the $0-2.0 \mathrm{~m}$ profile from $\mathrm{V} 8$ stage to maturity in two hybrids at PD 8 in the 2013 seasons in three water regimes $\left(I_{100}, I_{75}\right.$ and $\left.I_{50}\right)$. 
significantly $(\mathrm{P}<0.05)$ as the irrigated inputs decreased for both hybrids, and the highest WUE was found at $I_{75}$. Higher WUE at $I_{75}$ indicated a full use of irrigation, stored soil water, and rainfall (Howell 2001; Hao et al. 2015b), which is a target of crop improvement under water-limited conditions (Blum 2009). In our previous studies, significant differences in grain yield were found between $\mathrm{I}_{100}$ and $\mathrm{I}_{75}$ among Pioneer hybrids during 2011-2013 (Hao et al. 2015a, 2015b), while WUE at $\mathrm{I}_{75}$ was lower than $\mathrm{I}_{100}$ in 2012. The different findings may be due to the much less precipitation during the maize growing seasons of 2011 and 2012 compared to 2013 and 2014.

In this study, yield in the hybrid with Agrisure Artesian DT trait $(\mathrm{N} 75 \mathrm{H})$ did not differ with the conventional hybrid (N74R), due to the similar drought score in the two hybrids. However, we did find that the yield reduction by water stress at $\mathrm{I}_{50}$ for $\mathrm{N} 75 \mathrm{H}(4.22 \mathrm{t} / \mathrm{ha}$ ) was less than N74R $(4.78 \mathrm{t} / \mathrm{ha})$, demonstrating more yield stability for the DT hybrid. Moreover, $\mathrm{N} 75 \mathrm{H}$ extracted less soil water than $\mathrm{N} 74 \mathrm{R}$ at all the three water regimes, a characteristic found in our other studies with DT hybrids from Pioneer (Hao et al. 2015b).

In general, maize yield responses to increased planting density were reported to follow quadratic (Milander et al. 2016) or quadratic-plateau models (Hammer et al. 2009) in the high-rainfall and irrigated environments. The availability of resources per plant and yield will decrease or keep constant when the density is higher than optimum planting density (Sarlanguel et al. 2007). And the optimum planting density is based on detailed exploring genotype and environment (Assefa et al. 2016). A synthesis-analysis pointed out that a higher planting density is needed to achieve the maximum yield in the high-yield zones (Assefa et al. 2016). In a model study, the optimum planting density was affected by available soil water at planting (Lyon et al. 2003). However, tolerance to planting density in modern maize hybrids has been improved over the decades (Tollenaar and Wu 1999; Tollenaar and Lee 2002) such that the optimum planting density in the U.S. maize belt has increased by 0.1 plants $/ \mathrm{m}^{2} /$ year over the past 25 years (Fischer and Edmeades 2010). As planting density has increased, DT hybrids showed greater tolerance to water stress under moderate and high densities than the conventional hybrids (Cooper et al. 2014). In this study, planting density did not affect grain yield, ETc, or WUE for the conventional hybrid (N74R). However, yield and WUE significantly increased as the density increased for the DT hybrid $(\mathrm{N} 75 \mathrm{H})$.

\section{Biomass, HI, kernel weight, kernel number, and yield determination}

For both maize hybrids, grain yield was strongly $(\mathrm{P}<0.0001)$ determined by biomass at maturity, HI, and kernel weight. Similar results were also found in another two-year study with Pioneer hybrids (Hao et al. 2015b). Although 
a linear relationship between grain yield and kernel number was found in four hybrids in our previous study (Zhao et al. 2018), in this study grain yield was more related to kernel weight than kernel number. Consistent with previous studies (Colaizzi, Evett, and Howell 2011; Hao et al. 2015b; Magaia et al. 2017), water deficits decreased biomass at maturity, HI, and kernel weight. Instead of HI, an increase in biomass at maturity is the key driver for increased maize yield in the new hybrids (Zhao et al. 2015). In this study, reduced biomass was only found at $I_{50}$ as compared to $I_{100}$. It is significant that irrigation at the $\mathrm{I}_{75}$ level resulted in water savings as compared to $\mathrm{I}_{100}$ in this semiarid region. Averaged across years, planting densities, and hybrids, the kernel weights were 382.8, 366.7, and $282.6 \mathrm{mg}$ kernel $^{-1}$ at $\mathrm{I}_{100}, \mathrm{I}_{75}$, and $\mathrm{I}_{50}$, respectively, which were greater than the values reported in the previous studies on Pioneer hybrids (less than $300 \mathrm{mg} / \mathrm{kernel}$ ) (Hao et al. 2015b; Mounce et al. 2016; Tolk et al. 2016). Our previous study showed that Syngenta hybrids had greater kernel weight than Pioneer hybrids (Zhao et al. 2018). In this study, water stress at $I_{75}$ and $I_{50}$ reduced the kernel weight by $16.1 \mathrm{mg} /$ kernel and $100.2 \mathrm{mg} /$ kernel compared to $\mathrm{I}_{100}$, while there were no significant difference in kernel number among the three water regimes. Hao et al. (2015b) and Zhao et al. (2018) also reported that kernel weight was more sensitive to water stress than kernel number.

In this study, higher planting densities increased total aboveground biomass per square meter but decreased biomass per plant. Kernel number per $\mathrm{m}^{2}$ also increased under higher density, which may be caused by the increased number of ears per $\mathrm{m}^{2}$ instead of number of kernels per ear (Kruger et al. 2018). Kernel weight showed a decreasing trend under the higher density, especially in 2013, which may be influenced by the stressful environment during grain filling (Abendroth et al. 2011). Similar trends in kernel number and kernel weight were also reported in previous dryland and partially irrigated sites (Norwood 2001; Pavlista et al. 2010). For example, Echarte et al. (2000) found an increase in planting density from 5.0 to 14.5 plants $/ \mathrm{m}^{2}$ increased kernel number from $38 \%$ to $56 \%$ and decreased kernel weight by $6 \%$ to $17 \%$. In addition, there were no differences in biomass, HI, kernel weight, and kernel number between PD 8 and PD 10. This indicated that the optimal planting density should be in the range of 8-10 plants $/ \mathrm{m}^{2}$ in the research area, consistent with Marek et al. (2016). Although N74R had more kernels per square meter than N75H when averaged across years, water regimes, and planting densities, kernel number and kernel weight of N74R were more sensitive to planting density than $\mathrm{N} 75 \mathrm{H}$. That may be attributed to recent breeding efforts that have also produced hybrids that better tolerate the stresses created by increased plant density (Gaffney et al. 2015). Kernel weight of N74R decreased significantly following the increased densities while no differences were found in that of $\mathrm{N} 75 \mathrm{H}$ in 2013. Meanwhile, kernel number of N74R increased by $49.9 \%$ from PD 6 to PD 10, while that of N75H increased by $22.9 \%$ in 2013 . 


\section{Conclusion}

Regardless of year, hybrid, or planting density, no significant differences in grain yield were found between $\mathrm{I}_{100}$ and $\mathrm{I}_{75}$. However, $\mathrm{I}_{50}$ significantly reduced the grain yield by $4.78 \mathrm{t} / \mathrm{ha}$ for $\mathrm{N} 74 \mathrm{R}$ and $4.22 \mathrm{t} / \mathrm{ha}$ for $\mathrm{N} 75 \mathrm{H}$ compared to $\mathrm{I}_{100}$. Seasonal ETc decreased in water-limited conditions $\left(\mathrm{I}_{75}\right.$ and $\left.\mathrm{I}_{50}\right)$, and the highest WUE was found at $\mathrm{I}_{75}$ for both hybrids $\left(2.36 \mathrm{~kg} / \mathrm{m}^{3}\right.$ and $\left.2.23 \mathrm{~kg} / \mathrm{m}^{3}\right)$. For both hybrids, water deficits decreased biomass, HI, and kernel weight. However, differences in kernel number were not significant among three water regimes. Higher planting densities, on the other hand, increased biomass and kernel number per unit area, but decreased kernel weight, especially in 2013. Although N75H, with the Agrisure Artesian DT trait, did not have a yield benefit over the conventional hybrid N74R, $\mathrm{N} 75 \mathrm{H}$ provided greater yield stability under high plant densities when water stress increased. Planting a DT hybrid with a greater plant density may provide greater yield stability under water-limited conditions while also maintaining yield potential when moisture is sufficient. Overall, limited irrigation at $\mathrm{I}_{75}$ is an effective way to save water and maintain maize yield level in semiarid areas. In addition, DT hybrids showed a greater yield stability to plant density under water stress.

\section{Acknowledgments}

We are grateful to Texas A\&M AgriLife Research staff of Chance Reynolds, Choyce Reynolds, Brad Parker, Cole Pope, Bella Porras, Bronc Finch, and Preston Sirmon for their help in field and laboratory work. This research was supported in part by Texas A\&M AgriLife Research Cropping System Program, Syngenta-US Seeds, Inc., the USDA-Ogallala Aquifer Program, and the USDA National Institute of Food and Agriculture Hatch Project, USA (TEX09438).

\section{Disclosure statement}

No potential conflict of interest was reported by the authors.

\section{References}

Abendroth, L. J., R. W. Elmore, M. J. Boyer, and S. K. Marlay. 2011. Corn Growth and Development. PMR 1009. Ames, IA: Iowa State Univ. Ext.

Assefa, Y., P. V. V. Prasad, P. Carter, M. Hinds, G. Bhalla, R. Schon, M. Jeschke, S. Paszkiewicz, and I. A. Ciampitti. 2016. "Yield Responses to Planting Density for US Modern Corn Hybrids: A Synthesis-Analysis." Crop Science 56: 2802-2817. doi:10.2135/ cropsci2016.04.0215.

Blum, A. 2009. "Effective Use of Water (EUW) and Not Water-Use Efficiency (WUE) Is the Target of Crop Yield Improvement under Drought Stress." Field Crops Research 112: 119-123. doi:10.1016/j.fcr.2009.03.009.

Boomsma, C. R., and T. J. Vyn. 2008. "Maize Drought Tolerance: Potential Improvements through Arbuscular Mycorrhizal Symbiosis?” Field Crops Research 108: 14-31. doi:10.1016/ j.fcr.2008.03.002. 
Campos, H., M. Cooper, G. O. Edmeades, C. Löffler, J. R. Schussler, and M. Ibañez. 2006. "Changes in Drought Tolerance in Maize Associated with Fifty Years of Breeding for Yield in the US Corn Belt.” Maydica 51: 369-381.

Colaizzi, P. D., S. R. Evett, and T. A. Howell. 2011. "Corn Production with Spray, LEPA, and SDI." Proceedings of 23rd Annual Central Plains Irrigation Conference, Burlington, CO, 52-67.

Cooper, M., C. Gho, R. Leafgren, T. Tang, and C. Messina. 2014. "Breeding Drought-Tolerant Maize Hybrids for the US Corn-Belt: Discovery to Product." Journal of Experimental Botany 65: 6191-6204. doi:10.1093/jxb/eru064.

Duvick, D. N. 2005. “The Contribution of Breeding to Yield Advances in Maize (Zea Mays L.)." Advances in Agronomy 86: 83-145.

Echarte, L., S. Luque, F. H. Andrade, V. O. Sadras, A. Cirilo, M. E. Otegui, and C. R. C. Vega. 2000. "Response of Maize Kernel Number to Plant Density in Argentinean Hybrids Released between 1965 and 1993." Field Crops Research 68: 1-8. doi:10.1016/S0378-4290(00)00101-5.

Farfan, I.D.B., S.C. Murray, S. Labar, and D Pietsch. 2013. "A Multi-environment Trial Analysis Shows Slight Grain Yield Improvement in Texas Commercial Maize.” 149: 167176. doi:10.1016/j.fcr.2013.04.017.

Fischer, R. A., and G. O. Edmeades. 2010. "Breeding and Cereal Yield Progress." Crop Science 50: S85-S98. doi:10.2135/cropsci2009.10.0564.

Gaffney, J., J. Schussler, C. Löffler, W. Cai, S. Paszkiewicz, C. Messina, J. Groeteke, J. Keaschall, and M. Cooper. 2015. "Industry-Scale Evaluation of Maze Hybrids Selected for Increased Yield in Drought Stress Conditions of the US Corn Belt." Crop Science 55: 1608-1618. doi:10.2135/cropsci2014.09.0654.

Gheysari, M., H. W. Loescher, S. H. Sadeghi, S. M. Mirlatifi, M. J. Zareian, and G. Hoogenboom. 2015. "Chapter Three - Water-Yield Relations and Water Use Efficiency of Maize under Nitrogen Fertigation for Semiarid Environments: Experiment and Synthesis." Advances in Agronomy 130: 175-229.

Gheysari, M., S.-H. Sadeghi, H. W. Loescher, S. Amiri, M. J. Zareian, M. M. Majidi, P. Asgarinia, and J. O. Payero. 2017. "Comparison of Deficit Irrigation Management Strategies on Root, Plant Growth and Biomass Productivity of Silage Maize." Agricultural Water Management 182: 126-138. doi:10.1016/j.agwat.2016.12.014.

Hammer, G. L., Z. Dong, G. McLean, A. Doherty, C. Messina, J. Schussler, C. Zinselmeier, S. Paszkiewicz, and M. Cooper. 2009. "Can Changes in Canopy And/Or Root System Architecture Explain Historical Maize Yield Trends in the U.S. Corn Belt?" Crop Science 49: 299-312. doi:10.2135/cropsci2008.03.0152.

Hao, B., Q. Xue, T. H. Marek, K. E. Jessup, J. Becker, X. Hou, W. Xu, et al. 2015a. "Water Use and Grain Yield in Drought-Tolerant Corn in the Texas High Plains." Agronomy Journal 107: 1922-1930. doi:10.2134/agronj15.0133.

Hao, B., Q. Xue, T. H. Marek, K. E. Jessup, J. Becker, X. Hou, W. Xu, E. D. Bynum, and B. W. Bean. 2015b. "Soil Water Extraction, Water Use, and Grain Yield by Drought-Tolerant Maize on the Texas High Plains." Agricultural Water Management 155: 11-21. doi:10.1016/j.agwat.2015.03.007.

Hao, B., Q. Xue, T. H. Marek, K. E. Jessup, J. Becker, X. Hou, W. Xu, E. D. Bynum, and B. W. Bean. 2016. "Radiation Use Efficiency, Biomass Production, and Grain Yield in Two Maize Hybrids Differing in Drought Tolerance." Journal of Agronomy and Crop Science 202: 269-280. doi:10.1111/jac.12154.

Howell, T. A. 2001. "Enhancing Water Use Efficiency in Irrigated Agriculture." Agronomy Journal 93: 281-289. doi:10.2134/agronj2001.932281x.

Howell, T. A., A. Yazar, A. D. Schneider, D. A. Dusek, and K. S. Copeland. 1995. "Yield and Water Use Efficiency of Corn in Response to LEPA Irrigation." Transactions of the ASAE 38: 1737-1747. doi:10.13031/2013.28001. 
Jia, Q., L. Sun, S. Ali, Y. Zhang, D. Liu, M. Kamran, P. Zhang, Z. Jia, and X. Ren. 2018. “Effect of Planting Density and Pattern on Maize Yield and Rainwater Use Efficiency in the Loess Plateau in China." Agricultural Water Management 202: 19-32. doi:10.1016/j.agwat.2018.02.011.

Kruger, G. R., S. C. Mason, Z. Kmail, J. A. Golus, and J. J. Milander. 2018. "Seeding Rate Influence on Rainfed Maize Grain Yield and Components in the Western Corn Belt." Agrosystems, Geosciences \& Environment 1: 180025.

Li, J., R. Z. Xie, K. R. Wang, B. Ming, Y. Q. Guo, G. Q. Zhang, and S. K. Li. 2015. "Variations in Maize Dry Matter, Harvest Index, and Grain Yield with Plant Density." Agronomy Journal 107: 829-834. doi:10.2134/agronj14.0522.

Lyon, D. J., G. L. Hammer, G. B. McLean, and J. M. Blumenthal. 2003. "Simulation Supplements Field Studies to Determine No-Till Dryland Corn Population Recommendations for Semiarid Western Nebraska." Agronomy Journal 95: 884-891. doi:10.2134/agronj2003.8840.

Magaia, E., S. Famba, I. Wesström, R. Brito, and A. Joel. 2017. "Modelling Maize Yield Response to Plant Density and Water and Nitrogen Supply in a Semi-Arid Region." Field Crops Research 205: 170-181. doi:10.1016/j.fcr.2016.12.025.

Marek, T., D. Porter, N. Kenny, P. Gowda, and T. A. Howell. 2011. "Educational Enhancements to the Texas High Plains Evapotranspiration (ET) Network." Technical Report for the Texas Water Development Board. Amarillo: Texas A\&M AgriLife Res.

Marek, T. H., Q. Xue, W. Xu, P. Colaizzi, S. Amosson, B. Guerrero, and D. Porter. 2016. "Yield Performance of Commercial Corn Hybrids at Various Planting Densities and ET Levels.” USDA-Ogallala Aquifer Program Workshop, Amarillo, TX, March 8.

Milander, J. J., Z. Jukic, S. C. Mason, T. Glausha, and Z. Kmail. 2016. "Plant Population Influence on Maize Yield Components in Croatia and Nebraska." Crop Science 56: 2742-2750. doi:10.2135/cropsci2015.09.0565.

Mounce, R. B., S. A. O’Shaughnessy, B. C. Blaser, P. D. Colaizzi, and S. R. Evett. 2016. "Crop Response of Drought-Tolerant and Conventional Maize Hybrids in a Semiarid Environment." Irrigation Science 34: 231-244. doi:10.1007/s00271-016-0497-5.

Norwood, C. A. 2001. "Dryland Corn in Western Kansas: Effects of Hybrid Maturity, Planting Date, and Plant Population.” Agronomy Journal 93: 540-547. doi:10.2134/agronj2001.933540x. Nyakudya, I. W., and L. Stroosnijder. 2014. "Effect of Rooting Depth, Plant Density and Planting Date on Maize (Zea Mays L.) Yield and Water Use Efficiency in Semi-Arid Zimbabwe: Modelling with AquaCrop." Agricultural Water Management 146: 280-296. doi:10.1016/j.agwat.2014.08.024.

Passioura, J. 2006. "Increasing Crop Productivity When Water Is Scarce-From Breeding to Field Management.” Agricultural Water Management 80: 179-196. doi:10.1016/j.agwat.2005.07.012.

Pavlista, A. D., D. J. Lyon, D. D. Baltensperger, and G. W. Hergert. 2010. "Yield Components as Affected by Planting Dryland Maize in a Double-Skip Row Pattern." Journal of Crop Improvement 24: 131-141. doi:10.1080/15427520903565307.

Qian, C., Y. Yu, X. Gong, Y. Jiang, Y. Zhao, Z. Yang, Y. Hao, L. Li, Z. Song, and W. Zhang. 2016. "Response of Grain Yield to Plant Density and Nitrogen Rate in Spring Maize Hybrids Released from 1970 to 2010 in Northeast China." The Crop Journal 4: 459-467. doi:10.1016/j.cj.2016.04.004.

Ren, X., D. Sun, and Q. Wang. 2016. "Modeling the Effects of Plant Density on Maize Productivity and Water Balance in the Loess Plateau of China." Agricultural Water Management 171: 40-48. doi:10.1016/j.agwat.2016.03.014.

Rurinda, J., M. T. V. Wijk, P. Mapfumo, K. Descheemaeker, I. Supit, and K. E. Giller. 2015. "Climate Change and Maize Yield in Southern Africa: What Can Farm Management Do?" Global Change Biology 21: 4588-4601. doi:10.1111/gcb.13061. 
Sammons, B., J. Whitsel, L. G. Stork, W. Reeves, and M. Horak. 2014. "Characterization of Drought-Tolerant Maize MON 87460 for Use in Environmental Risk Assessment.” Crop Science 54: 719-729. doi:10.2135/cropsci2013.07.0452.

Sarlanguel, T., F. H. Andrade, P. A. Calvifho, and L. C. Purcell. 2007. "Why Do Maize Hybrids Respond Differently to Variations in Plant Density?” Agronomy Journal 99: 984-991. doi:10.2134/agronj2006.0205.

SAS Institute Inc. 2014. SAS/STAT 9.4 User's Guide. Cary, NC: SAS Institute.

Scanlon, B. R., R. C. Reedy, J. B. Gates, and P. H. Gowda. 2010. "Impact of Agroecosystems on Groundwater Resources in the Central High Plains, USA." Agriculture, Ecosystems and Environment 139: 700-713. doi:10.1016/j.agee.2010.10.017.

Testa, G., A. Reyneri, and M. Blandino. 2016. "Maize Grain Yield Enhancement Throughhigh Plant Density Cultivation with Different Inter-Row and Intra-Row Spacings." European Journal of Agronomy 72: 28-37. doi:10.1016/j.eja.2015.09.006.

Tokatlidis, I. S., V. Has, V. Melidis, I. Has, I. Mylonas, G. Evgenidis, A. Copandean, E. Ninou, and V. A. Fasoula. 2004. "A Review of Maize Hybrids' Dependence on High Plant Populations and Its Implications for Crop Yield Stability.” Field Crops Research 120: 345-351. doi:10.1016/j.fcr.2010.11.006.

Tolk, J. A., S. R. Evett, W. Xu, and R. C. Schwartz. 2016. "Constraints on Water Use Efficiency of Drought Tolerant Maize Grown in a Semi-Arid Environment." Field Crops Research 186: 66-77. doi:10.1016/j.fcr.2015.11.012.

Tollenaar, M., and E. A. Lee. 2002. "Yield Potential, Yield Stability and Stress Tolerance in Maize.” Field Crops Research 75: 161-169. doi:10.1016/S0378-4290(02)00024-2.

Tollenaar, M., and J. Wu. 1999. "Yield Improvement in Temperate Maize Is Attributable to Greater Stress Tolerance." Crop Science 39: 1597-1640. doi:10.2135/cropsci1999.3961597x.

Wang, Y., B. Janz, T. Engedal, and A. D. Neergaard. 2017. "Effect of Irrigation Regimes and Nitrogen Rates on Water Use Efficiency and Nitrogen Uptake in Maize." Agricultural Water Management 179: 271-276. doi:10.1016/j.agwat.2016.06.007.

Xue, Q., T. H. Marek, W. Xu, and J. Bell. 2017. "Irrigated Corn Production and Management in the Texas High Plains." Journal of Contemporary Water Research \& Education 162: 31-41. doi:10.1111/j.1936-704X.2017.03258.x.

Zhan, A., H. Schneider, and J. P. Lynch. 2015. "Reduced Lateral Root Branching Density Improves Drought Tolerance in Maize.” Plant Physiology 168: 1603-1615. doi:10.1104/pp.15.00187.

Zhao, J., Q. Xue, K. E. Jessup, B. Hao, X. Hou, T. H. Marek, W. Xu, S. R. Evett, S. A. O'Shaughnessy, and D. K. Brauer. 2018. "Yield and Water Use of Drought-Tolerant Maize Hybrids in a Semiarid Environment." Field Crops Research 216: 1-9. doi:10.1016/j.fcr.2017.11.001.

Zhao, J., X. Yang, X. Lin, G. F. Sassenrath, S. Dai, S. Lv, X. Chen, F. Chen, and G. Mi. 2015. "Radiation Interception and Use Efficiency Contributes to Higher Yields of Newer Maize Hybrids in Northeast China." Agronomy Journal 107: 1473-1480. doi:10.2134/agronj14.0510.

Ziolkowska, J. R. 2015. "Shadow Price of Water for irrigation-A Case of the High Plains." Agricultural Water Management 153: 20-31. doi:10.1016/j.agwat.2015.01.024. 